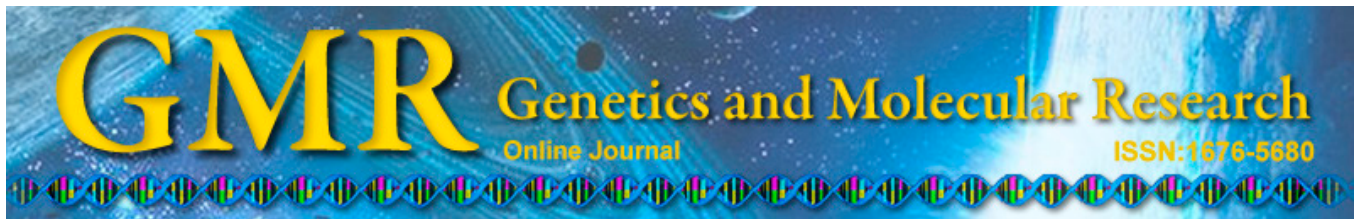

\title{
Expression and genomic integration of transgenes after Agrobacterium-mediated transformation of mature barley embryos
}

\author{
C. Uçarlı ${ }^{1}$, F. Tufan ${ }^{1}$ and F. Gürel ${ }^{1,2}$ \\ ${ }^{1}$ Department of Molecular Biology and Genetics, Faculty of Science, \\ Istanbul University, Vezneciler, Istanbul, Turkey \\ ${ }^{2}$ Research and Application Center for Genetic Engineering and Biotechnology, \\ Istanbul University, Vezneciler, Istanbul, Turkey \\ Corresponding author: C. Uçarlı \\ E-mail: ucarlicu@istanbul.edu.tr
}

Genet. Mol. Res. 14 (1): 1096-1105 (2015)

Received May 16, 2014

Accepted October 8, 2014

Published February 6, 2015

DOI http://dx.doi.org/10.4238/2015.February.6.13

\begin{abstract}
Mature embryos in tissue cultures are advantageous because of their abundance and rapid germination, which reduces genomic instability problems. In this study, 2-day-old isolated mature barley embryos were infected with 2 Agrobacterium hypervirulent strains (AGL1 and EHA105), followed by a 3-day period of cocultivation in the presence of L-cystein amino acid. Chimeric expression of the $\beta$-glucuronidase gene (gusA) directed by a viral promoter of strawberry vein banding virus was observed in coleoptile epidermal cells and seminal roots in 5-day-old germinated seedlings. In addition to varying infectivity patterns in different strains, there was a higher ratio of transient $\beta$-glucuronidase expression in developing coleoptiles than in embryonic roots, indicating the high competency of shoot apical meristem cells in the mature embryo. A total of 548 explants were transformed and 156 plants developed to maturity on G418 media after 18-25 days. We detected transgenes in $74 \%$ of the screened plant leaves by polymerase chain reaction, and $49 \%$ of these
\end{abstract}


expressed neomycin phosphotransferase II gene following AGL1 transformation. Ten randomly selected $\mathrm{T}_{0}$ transformants were analyzed using thermal asymmetric interlaced polymerase chain reaction and 24 fragments ranged between 200-600 base pairs were sequenced. Three of the sequences flanked with transferred-DNA showed high similarity to coding regions of the barley genome, including alpha tubulin5, homeobox 1, and mitochondrial 16S genes. We observed 70-200-base pair filler sequences only in the coding regions of barley in this study.

Key words: Barley; Mature embryo; Tail-PCR

\section{INTRODUCTION}

Mature embryos of cereals have been transformed electrophoretically with exogenous DNA (Ahokas, 1989), by incubation of embryos in a DNA solution (Töpfer et al., 1989) and tissue electroporation (Dekeyser et al., 1990; Gürel and Gözükırmızı, 2000). Particularly, shoot meristematic segments of embryos are attractive targets for gene transfer in Gramieae species as they germinate quickly and grow into plants directly or through a callus phase (Sticklen and Oraby, 2005). Induction of the regenerative type of callus from mature embryos is a very genotype-dependent process and requires extensive optimization for tissue cultures (Bregitzer, 1992; Gürel et al., 2009). Furthermore, obtaining transgenic plants through regeneration from the callus phase is technically difficult because of the reduced regeneration of undifferentiated cells in culture (Sticklen and Oraby, 2005) and absence of effective selection systems (Padilla and Burgos, 2010). In contrast, seedlings produced through direct germination can be used to obtain clonal transformant plants by eliminating chimerism, selfing the $\mathrm{T}_{0}$ generation, and by efficient selection of the related trait. For example, direct germination from shoot apices without an intervening callus phase have been widely applied in transformed woody plants and some monocot species (Cho et al., 2003; Yookongaew et al., 2007; Jha et al., 2011; Yang et al., 2013).

Agrobacterium-mediated transformation represents an essential tool for both fundamental and applied research in plant biology (Lacroix and Citovsky, 2013). Although successful transformation of barley has been achieved using biolistics and Agrobacterium-mediated gene transfer (Wan and Lemaux, 1994; Tingay et al., 1997; Bartlett et al., 2008), the frequency of transgenic production remains low and is limited to model varieties such as Igri and Golden promise (Goedeke et al., 2007). A more universal transformation procedure for barley genotypes may be useful for studying gene function in cereals. Electroporation of mature embryos has been shown to be effective for transferring foreign genes into germinating barley embryos (Gürel and Gözükırmızı, 2000). However, because of decreased cell viability, further plant growth is affected greatly with this method. The high resistance of barley to widely used antibiotics such as kanamycin and geneticin (G418) create difficulties in efficient selection of plantlets and frequently results in albino phenotypes. Although Agrobacterium is routinely used for barley transformation, integration patterns in the barley genome are not well-understood. More stable generations with reduced gene silencing are associated with the integration of T-DNA, mostly into euchromatic regions (Travella et al., 2005; Barlett et al., 2008).

In this study, we transformed freshly isolated and cultured mature embryos of a Turkish commercial variety (cv. Tokak 157/37) to determine the infection level of Agrobacterium in early developing parts of the embryos. Addition of plant growth regulator thidiazuron into 
the selection medium was beneficial for enhancing regenerated plantlet numbers by eliminating the albino phenotype. Thermal asymmetric interlaced polymerase chain reaction (TAILPCR) was optimized by designing specific and arbitrary degenerate primers to identify flanking genomic regions to both the right and left borders of T-DNA.

\section{MATERIAL AND METHODS}

\section{Plant material and culture conditions}

Hordeum vulgare cv. Tokak 157/37 was used as the plant material. Seeds were surface-sterilized with $25 \%$ sodium hypochlorite for $20 \mathrm{~min}$ and rinsed with sterile distilled water 3 times for $10 \mathrm{~min}$. Mature embryos (MEs) were dissected from the endosperm under aseptic conditions, immersed in absolute ethanol for $20 \mathrm{sec}$, and followed by rinsing with sterile distilled water three times for $1 \mathrm{~min}$. Explants were later cultured on MS (Murashige and Skoog, 1962) medium (3\% sucrose, $4.4 \mathrm{~g} / \mathrm{L}$ MS basal salt, $0.1 \% \mathrm{MS}$ vitamin, $0.9 \%$ agar, $\mathrm{pH} 5.8$ ) and kept in a controlled growth chamber (EKOCHL 1500, Angelontoni, Italy) in the dark at $25^{\circ} \mathrm{C}$.

\section{Agrobacterium-mediated transformation}

Agrobacterium tumefaciens strains EHA105 (Hood et al., 1993) and AGL1 strains were used for transformation. A binary vector (pCambia2301) was transferred to bacterial strains using a freeze-thaw method (Höfgen and Willmitzer, 1988). The vector contains $\beta$-glucuronidase (gusA) gene driven by the strawberry vein banding virus promoter (Wang et al., 2000) and neomycin phosphotransferase II (npt II) gene cloned between cauliflower mosaic virus $35 \mathrm{~S}$ promoter and nos terminator.

An outline of the transformation procedure is shown in Figure 1. Bacterial strains were grown in Luria-Bertani medium ( $1 \%$ tryptone, $0.5 \%$ yeast extract and $1 \% \mathrm{NaCl}, \mathrm{pH} 7.2$ ) supplemented with $50 \mathrm{mg} / \mathrm{L}$ kanamycin and $50 \mathrm{mg} / \mathrm{L}$ rifampicin for 2 days at $28^{\circ} \mathrm{C}$ with shaking at 180 $\mathrm{rpm}$. During the $\log$ phase $\left(\mathrm{OD}_{600}=0.6-0.8\right)$, cells were collected by centrifugation at $3750 \mathrm{~g}$ for

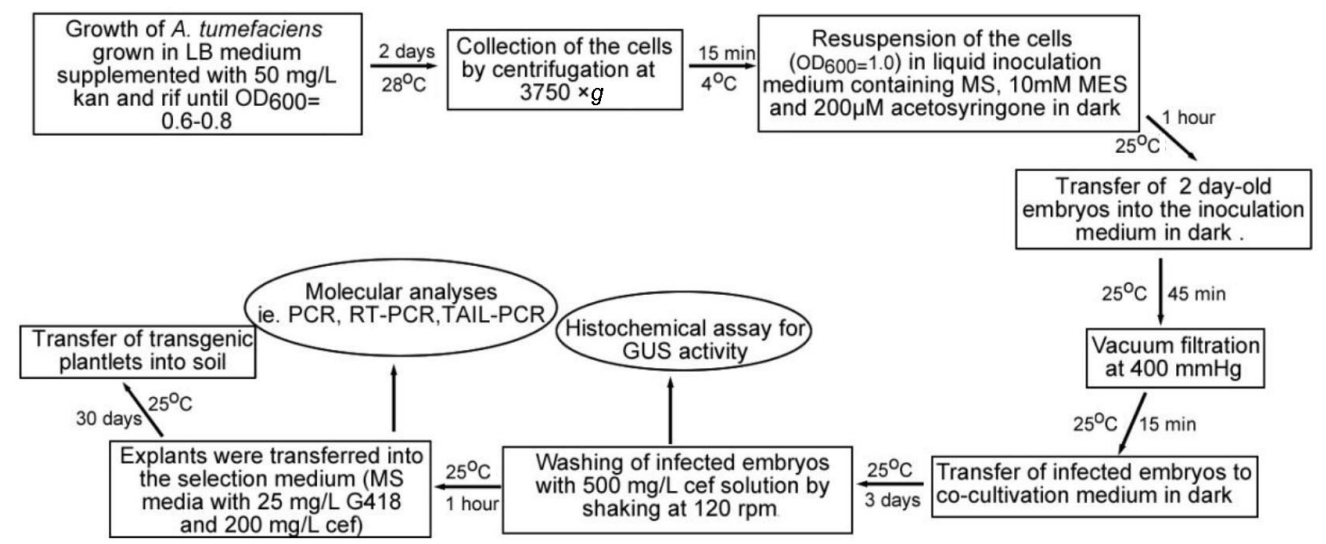

Figure 1. Schematic diagram of Agrobacterium-mediated transformation of mature embryos cef: cefotaxime, kan: kanamycin, rif: rifampicin. 
$15 \mathrm{~min}$ and then resuspended in liquid inoculation medium containing MS, $10 \mathrm{mM}$ 2- $\mathrm{N}$-morpholino ethanesulfonic acid (MES) and $200 \mu \mathrm{M}$ acetosyringone. Bacterial cell density was adjusted to give an $\mathrm{OD}_{600}$ of 1.0 for inoculation. The inoculation medium was incubated at room temperature $\left(25^{\circ} \mathrm{C}\right)$ in the dark for $1 \mathrm{~h}$. Two-day-old embryos were transferred into the inoculation medium and incubated for $45 \mathrm{~min}$. Next, vacuum filtration was carried out at $400 \mathrm{mmHg}$ for $15 \mathrm{~min}$. Following the inoculation period, the embryos were blotted onto sterile filter paper and transferred into co-cultivation medium containing $4.4 \mathrm{~g} / \mathrm{L}$ MS salt, $0.1 \% \mathrm{MS}$ vitamin, $3 \%$ sucrose, $0.9 \%$ agar and $800 \mathrm{mg} / \mathrm{L} \mathrm{L-cystein} \mathrm{(pH} \mathrm{5.6)} \mathrm{and} \mathrm{incubated} \mathrm{in} \mathrm{the} \mathrm{dark} \mathrm{for} 3$ days at $25^{\circ} \mathrm{C}$. After the co-cultivation period, explants were transferred to cefotaxime solution $\left(500 \mathrm{mg} / \mathrm{L}\right.$ in $\left.\mathrm{dH}_{2} \mathrm{O}\right)$ and washed for $1 \mathrm{~h}$ by shaking at $120 \mathrm{rpm}$. Explants were subsequently transferred into selection medium [MS media with $40 \mathrm{mg} / \mathrm{L}$ geneticin (G418) and $200 \mathrm{mg} / \mathrm{L}$ cefotaxime] as well as medium containing 2 $\mathrm{mg} / \mathrm{L}$ thidiazuron.

\section{Histochemical assay and expression of transgenes}

T-DNA delivery was determined by histochemical assays of GUS activity (Jefferson et al., 1987). Five-day-old germinated embryos were immersed in a solution including $6 \mathrm{mM} 5$ bromo-4-chloro-3-indolyl- $\beta$-D-glucuronide, $1.5 \mathrm{mM}$ potassium ferricyanide, $1.5 \mathrm{mM}$ potassium ferrocyanide, $20 \%(\mathrm{v} / \mathrm{v})$ methanol, and $0.8 \%(\mathrm{v} / \mathrm{v})$ Triton $100 \mathrm{X}$ and incubated overnight at $55^{\circ} \mathrm{C}$. GUS staining in tissues was observed under a stereomicroscope (Olympus SZX7, Tokyo, Japan). GUS activity was expressed as explant numbers with at least 1 gusA expressing focus. Expression of the npt II gene in plantlets was analyzed by reverse transcription-PCR (RTPCR) using the 700-base pair (bp) fragment of $n p t$ II amplified by primers of 5'-ATCGGGAG CGGCGATACCGTA-3' and 5'-GAGGCTATTCGGCTATGACT G-3'. Alpha-tubulin was used as reference gene with the primers 5'-GAAAGGCGTCTTCGT ACT CG-3' and 5'-GAGTGGGTGGACAGGACACT-3'. For RT-PCR, total RNA was extracted from barley leaves using the SV Total RNA Isolation System (Z3100, Promega, Madison, WI, USA) according to manufacturer instructions. PCR was performed using $1 \mu \mathrm{g}$ total RNA and the One-step RT-PCR kit (RR024, Takara, Shiga, Japan) according to manufacturer instructions.

\section{Integration analyses by TAIL-PCR}

The presence of transgenes was examined by PCR using the primers 5'-GGTGGGAAAGCG CGTTACAAG-3' and 5'-GTTACGCGTTGCTTCCGCCA-3' for gusA and same primers used for RT-PCR analyses of the $n p t$ II gene. Genomic DNA was isolated from leaves using the cetyltriethylammonium bromide method (Weining and Langridge, 1991). PCR was performed in $25-\mu \mathrm{L}$ volume, containing 50 ng genomic DNA, $2 \mathrm{mM} \mathrm{MgCl}$, $200 \mu \mathrm{M}$ of each dNTP, $10 \mathrm{pM}$ of each primer, and $0.5 \mathrm{U}$ Taq DNA polymerase (EP0402, Fermentas, Vilnius, Lithuania). PCR conditions were: $95^{\circ} \mathrm{C} ; 5 \mathrm{~min}, 95^{\circ} \mathrm{C} ; 1 \mathrm{~min}, 55^{\circ} \mathrm{C} ; 1 \mathrm{~min}$; and $72^{\circ} \mathrm{C} ; 1 \mathrm{~min}$. TAIL-PCR was performed as described by Liu and Whittier (1995). We designed 4 nested and specific primers to the T-DNA right border of the pCAMBIA 2013 plasmid: SP1: 5'-TAACAAGAA AGGGATCTTCACTCG-3', SP2: 5'-AGCGCGCAAACTAGGATAAA-3', SP3: 5'-GCGCG GTGTCATCTATGTTACT-3', and SP4: 5'-AGGATATATTGGCGGGTAAA CCTA-3'. Each of these primers was used with 4 arbitrary short degenerate primers that were modified as AD1: 5'-ATCGAGTATGGAGTT-3', AD2: 5'-AGTCGACAGAAATGA-3', AD3: 5'-TGAC GAGAGATATGA-3', and AD4: 5'-TGACGACTGATTGA-3'. Specific nested prim- 
ers developed by Liu (1995) (TL1, 2, and 3) for the left border were used to obtain flanking sequences out of the left border. After secondary and tertiary reactions, putative target-specific PCR bands were purified from agarose gels and cloned into the $\mathrm{pCR}^{\mathrm{TM}} 4-\mathrm{TOPO}$ vector (Invitrogen Life Technologies, Carlsbad, CA, USA) for sequencing.

\section{Database search}

Flanking sequences were analyzed using the IPK (http://webblast.ipk-gatersleben.de/ barley/) and NCBI (http://www.ncbi.nlm.nih.gov/BLAST/) databases for nucleotide similarities based on the BLASTN algorithm.

\section{RESULTS}

\section{Transgene expression and seedlings growth}

Chimeric expression of gusA was examined in half of the seedlings from each strain transformation. Coleoptiles with the Zadoks scale 07-09 showed varying intensities of GUS activity (Figure 2A). Numbers of gusA-expressing foci ranged from 1-10 in coleoptile sections (Figure 2B and C) in most of the seedlings, with 1 exception that was stained blue (Figure 2D). GUS activity was rarely observed in seminal roots (Figure 2E). Numbers of explants with gusA-expressing foci were comparable between coleoptile and seminal roots (Table 1). For the AGL1 strain, numbers of explants with GUS activity in both coleoptile and seminal roots was significantly $(\mathrm{P} \leq 0.01)$ higher than in those with GUS activity in only their seminal roots. Analysis of variance showed that using the EHA105 strain rather than AGL1 yielded significantly $(\mathrm{P} \leq 0.001)$ fewer explants with GUS activity.

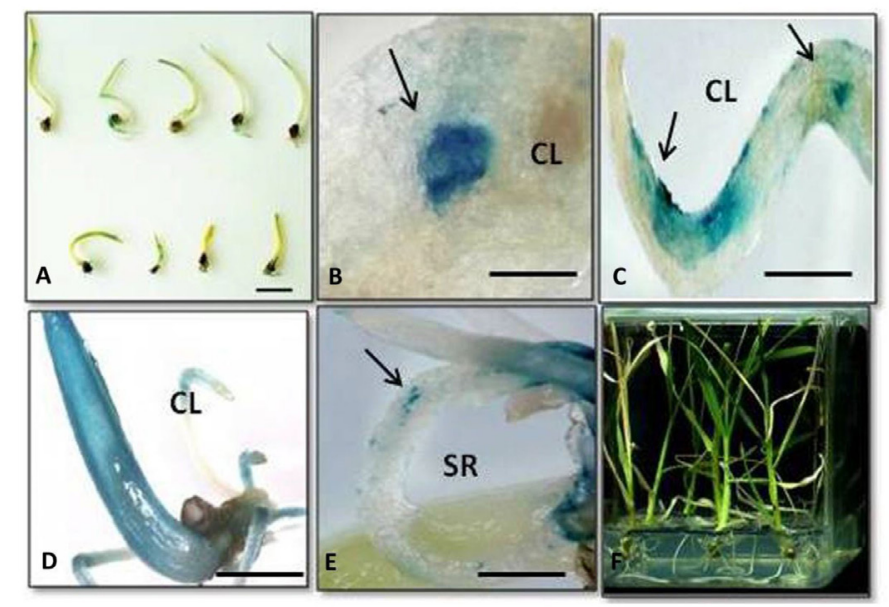

Figure 2. A. Histochemical gusA expression in transformant seedlings grown from mature embryos; B, C, D, E. Embryonic and seminal roots; F. plantlet regeneration on MS media supplemented with $40 \mathrm{mg} / \mathrm{L} \mathrm{G} 418$ and $2 \mathrm{mg} / \mathrm{L}$ TDZ. (CL: coleoptile, SR: seminal roots). Bars are $10 \mathrm{~mm}$ in A (magnification $1 \mathrm{X}$ ), $0.5 \mathrm{~mm}$ in B (magnification $50 \mathrm{X}$ ), $1 \mathrm{~mm}$ in $\mathrm{C}$ (magnification 25X), $2 \mathrm{~mm}$ in $\mathrm{D}$ (magnification 10X), and $1 \mathrm{~mm}$ in $\mathrm{E}$ (magnification 25X). 
A total of 69 and $45 \%$ of seedlings continued to grow in G418 media following AGL1 and EHA105 transformation, respectively (Table 1). In the absence of thidiazuron addition, the ratio of maintaining shoot growth decreased significantly $(32 \%$ with $\mathrm{P} \leq 0.01)$ following EHA105 transformation. We did not compare the effect of thidiazuron on AGL1 transformants. Leaves of transformant plantlets were phenotypically not albino, despite exposure to G418 for up to 30 days (Figure 2F). RT-PCR analyses carried out 26 days after transformation showed that 24 of the PCR-positive plants also expressed npt II gene in their leaves (Figure 3A).

Table 1. Numbers of embryos transiently expressing gusA in different parts of embryonic tissues after transformation with EHA105 and AGL1 strains. Mean numbers of explants with gusA expression were scored in seedlings with Zadocks scale 07-09.

\begin{tabular}{lccccc}
\hline $\begin{array}{l}\text { Agrobacterium } \\
\text { strain/plasmid }\end{array}$ & $\begin{array}{c}\text { Total No. of } \\
\text { transformed } \\
\text { embryos* }\end{array}$ & $\begin{array}{c}\text { Mean No. of } \\
\text { explants with GUS } \\
\text { activity in coleoptile } \\
\text { and seminal roots }\end{array}$ & $\begin{array}{c}\text { Mean No. of } \\
\text { explants with GUS } \\
\text { activity in only } \\
\text { coleoptile }\end{array}$ & $\begin{array}{c}\text { No. of G418 } \\
\text { resistant seedlings } \\
\text { (+TDZ) }\end{array}$ & $\begin{array}{c}\text { Transformant } \\
\text { confirmation of G418 } \\
\text { resistant seedlings } \\
\text { by PCR }\end{array}$ \\
\hline EHA105/p Cambia2301 & 276 & $15.7 \pm 0.7^{\mathrm{b}}$ & $11 \pm 0.6^{\mathrm{b}}$ & 62 & 36 \\
AGL1/p Cambia2301 & 272 & $23 \pm 0.5^{\text {a }}$ & $18.7 \pm 0.4^{\mathrm{a}}$ & 94 & 70 \\
\hline
\end{tabular}

Forty-five embryos were used in each experiment with 6 replicates $(\mathrm{N}=6)$. Data were subjected to student $\mathrm{t}$-test to assess statistical significance between strains using the GraphPad Prism 5. Columns with different letters show significantly different GUS activity with different strains at the $\mathrm{P} \leq 0.01 *$ Half of the embryos were used for the $\mathrm{X}$-Gluc assay and the other half were grown in selection medium.
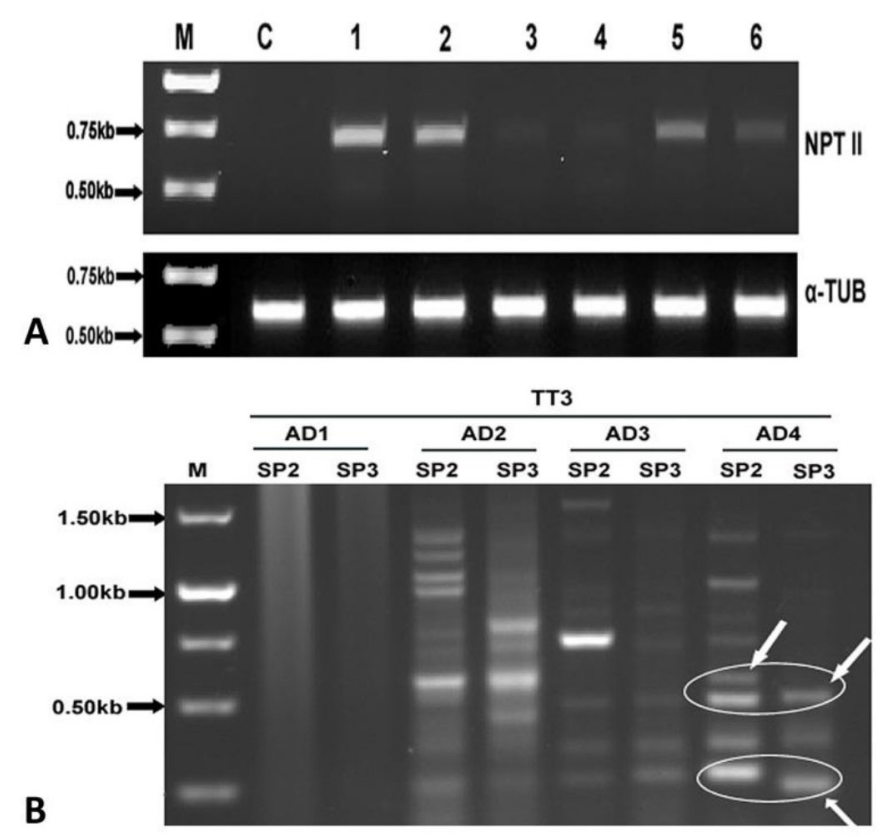

Figure 3. A. Expression analysis of $n p t$ II by RT-PCR. Alpha-tubulin was used as reference gene in RT-PCR. Lane $M=$ marker DNA (Fermentas $1 \mathrm{~kb}$ ladder); lane $C=$ DNA from untransformed plant; lanes $1-6=\mathrm{T}_{0}$ transformed plants. B. TAIL-PCR products of the Tokak157/37 transformant, TT3. Secondary and tertiary reactions were performed with SP2 and SP3 specific primers, respectively, and in each reaction, the same AD primer was used with specific primers. Arrows represent specific amplicons from secondary and tertiary reactions. 


\section{Integration of T-DNA}

Twenty-four amplified sequences ranging 200-600 bp were selected based on their expected size differences between secondary and tertiary reactions (Figure 3B). Generally, the amplification efficiencies of $\mathrm{AD} 3$ and $\mathrm{AD} 4$ were higher than $\mathrm{AD} 1$ and $\mathrm{AD} 2$ for obtaining fragments. Based on BLASTN analysis, 12 of the 24 specific sequences showed significant homology either to the barley genome or pCambia2301 according to the threshold criteria (threshold identity and expected values were higher than $75 \%$ and smaller than e-20, respectively). Among the 12 sequences, only $7(29 \%)$ showed similarity to the barley genome, while the remaining were vector sequences (Table 2). Five of these sequences were obtained using specific primers designed for the right border, while the other 2 flanked the left border regions of T-DNA.

According to BLASTN analysis, 2 sequences of the specific fragments obtained for the right border ( 5 fragments) integrated into the coding regions of the transformant barley's genome, including the alpha tubulin5 and homeobox genes. We obtained flanked sequences to alpha tubulin5 using 3 different AD primers (AD1, AD2, and AD3) (data not shown). The filler sequences of approximately $70 \mathrm{bp}$ were found between the genes of alpha tubulin5 and homeobox 1, and barley genome. The other 3 fragments on the right border integrated into the noncoding regions of barley and contained no filler sequences. One of the specific fragments obtained from the left border ( 2 fragments) showed high similarity to the mitchondrial $16 \mathrm{~S}$ gene in barley (75\%). This sequence contained a filler sequence of approximately $200 \mathrm{bp}$ in length. The other fragment has a vector backbone out of the T-DNA left border that is $259 \mathrm{bp}$ in length. This fragment was amplified using the AD1 primer and nested primer for T-DNA left border as suggested by Liu et al. (1995). These results showed that T-DNA integrations occurred in chromosomes $7 \mathrm{H}, 4 \mathrm{H}$, and $1 \mathrm{H}$ according to highest similarity and smallest e-value.

Table 2. T-DNA integration sites in the barley genome revealed by TAIL-PCR analyses.

\begin{tabular}{|c|c|c|c|c|c|}
\hline $\begin{array}{l}\text { Transformant } \\
\text { barley lines }\end{array}$ & $\begin{array}{l}\text { Arbitrary degenerate } \\
\text { primers }\end{array}$ & Accession No. & Integration site & Length (bp) & Similarity (\%) \\
\hline $\mathrm{TT} 1 *$ & AD3 & AM502848 & Alpha tubulin 5 & 295 & 80 \\
\hline TT3* & AD4 & CAJW012088029 & morex_contig_2088029 & 212 & 98 \\
\hline TT4* & AD3 & CAJW011645141 & morex_contig_1645141 & 150 & 99 \\
\hline TT5* & $\mathrm{AD} 2$ & - & pCambia 2301 & 157 & 100 \\
\hline TT5* & AD3 & - & pCambia2301 & 149 & 99 \\
\hline TT7* & $\mathrm{AD} 2$ & - & pCambia2301 & 151 & 98 \\
\hline TT7* & AD3 & - & pCambia2301 & 150 & 99 \\
\hline TT8* & AD2 & - & pCambia2301 & 150 & 99 \\
\hline TT9* & AD3 & FJ477091.1 & HOX-1 & 515 & 80 \\
\hline TT9* & AD3 & CAJW011551889 & morex_contig_1551889 & 157 & 99 \\
\hline $\mathrm{TT} 10^{* *}$ & $\mathrm{AD} 1$ & & pCambia2301 & 259 & 99 \\
\hline TT9** & $\mathrm{AD} 2$ & KC912688 & Mit16S & 568 & 75 \\
\hline
\end{tabular}

Threshold identity and expected values were adjusted to $\geq 75$ and $\leq$ e-20, respectively. ${ }^{*}$ Nested primers specific to the T-DNA right border were used. **Nested primers specific to the T-DNA left border were used Mit: mitchondrial genome.

\section{DISCUSSION}

We developed an improved procedure for transforming Tokak157/37 mature embryos by adding L-cystein as an antinecrotic substance and thidiazuron for shoot induction during selection. The use of L-cystein for enhancing cell viability after Agrobacterium infection has 
been demonstrated previously in rice and soybean (Enriquez-Obregon et al., 1999; Olhoft and Sommers, 2001). Albino phenotype in seedlings grown in selection medium dramatically decreased with the addition of thidiazuron through an unknown mechanism.

Higher transient expression of gusA detected in the barley coleoptile compared to roots showed that most recipient cells of T-DNA transfer may be located in the shoot apical meristem of mature embryos. Mutation studies in rice have indicated that coleoptile and epiblast differentiation are strongly dependent on the shoot apical meristem, while the radicle and scutellum are not (Satoh et al., 1999). Lower gusA expression in seminal roots may have occurred because of this regulatory role of the shoot apical meristem during barley embryogenesis. Embryonic roots are developed from the root meristem by cell elongation rather than cell division in the beginning of germination (Luxová, 1986). Low cell division in root meristem and patterns of primary seminal root formation may determine the numbers of competent cells of root primordia.

Transient expression of any gene can be achieved in the coleoptile and barley seedlings can be grown using the procedure described in this study. This approach may particularly be useful for examining transient expression patterns of chimeric genes and developing transient assay systems to evaluate plant stress responses (Nagy et al., 2011). Use of Agrobacteriummediated gene transfer also prevents cell damage caused by physical gene transfer methods which may induce disease-responsive genes during evaluation of pathogenic effects (Nelson and Bushnell, 1997). However, the procedure requires improvement to eliminate chimerism to produce clonal transgenic plants.

The promoter of the gusA gene used in this study was isolated from strawberry vein banding caulimovirus and has $60 \%$ homology with the $35 \mathrm{~S}$ cauliflower mosaic virus promoter (Wang et al., 2000). Similiarly to transformed tobacco cultures, this promoter was efficient for driving constitutive gusA expression in barley cells. Complex rearrangements of T-DNA integrations even resulting in bacterial genome integration into plant chromosome have been reported previously (Ülker et al., 2008). An average of half of the assessed barley lines were shown to carry 1 or more vector backbone sequences by DNA hybridization (Lange et al., 2006). De Buck et al. (2000) also reported that vector backbone DNA is much more frequently linked to the left than to the right border of T-DNA. TAIL-PCR is a fast and effective method for isolating unknown genomic sequences flanked to specific vector regions. This method does not require laborious preparations and the use of radioactive probes in DNA hybridizations. Although the method was only recently developed (Liu and Chen, 2007; Yang et al., 2011), primer design appears to be crucial for eliminating nonspecific PCR bands. For example, we obtained the same flanking sequence (alpha tubulin 5) from a transformant line using 3 different $\mathrm{AD}$ primers. Although we did not determine copy numbers, our results clearly show that $\mathrm{T}$ DNA integration occurred randomly in coding and non-coding regions in the barley genome, including in a mitochondrial gene.

In conclusion, mature embryo transformation has advantages over immature-embryo derived cultures in barley, which is recalcitrant to genetic manipulations and in vitro regeneration. Mature embryos are easy to handle, germinate quickly, represent a transient expression system, and enables analysis of integration patterns in short periods of time.

\section{ACKNOWLEDGMENTS}

Research supported by Scientific Research Projects Coorfination Unit of Istanbul Uni- 
versity (Projects \#2940 and \#4115). The authors thank Dr. Amit Galon for the pCambia2013 construct.

\section{REFERENCES}

Ahokas H (1989). Transfection of germinating barley seed electrophoretically with exogenous DNA. Theor. Appl. Genet. 27: 469-472.

Bartlett JG, Alves SC, Smedley M, Snape JW, et al. (2008). High-throughput Agrobacterium-mediated barley transformation. Plant Methods 4: 22.

Bregitzer P (1992). Plant regeneration and callus type in barley: effects of genotype and culture medium. Crop Sci. 32: 1108-1112.

Cho MJ, Choi HW, Okamoto D, Zhang S, et al. (2003). Expression of green fluorescent protein and its inheritance in transgenic oat plants generated from shoot meristematic cultures. Plant Cell Rep. 21: 467-447.

De Buck SD, De Wilde C, Van Montagu M and Depicker A (2000). T-DNA vector backbone sequences are frequently integrated into the genome of transgenic plants obtained by Agrobacterium-mediated transformation. Mol. Breeding 6: 459-468.

Dekeyser R, Inze D and Van Montago M (1990). Transgenic plants. In: Gene manipulation in plant improvement (Gustafson JP, ed.). Plenum Press, New York, pp. 237-250.

Enriquez-Obregon GA, Prieto-Samsonov D, De la Riva GA, Perez M, et al. (1999). Agrobacterium-mediated Japonica rice transformation: a procedure assisted by an antinecrotic treatment. Plant Cell Tiss. Organ Cult. 59: 159-168.

Goedeke S, Hensel G, Kapusi E, Gahrtz M, et al. (2007). Transgenic barley in fundamental research and biotechnology. Trans. Plant J. 1: 104-117.

Gürel F and Gözükırmızı N (2000). Optimization of gene transfer into barley (Hordeum vulgare L.) mature embryos by tissue electroporation. Plant Cell Rep. 19: 787-791.

Gürel F, Karakas O, Albayrak G and Ari S (2009). Regeneration capacity of mature embryo-derived callus in barley (Hordeum vulgare L.) Acta Biol. Hung. 60: 309-319.

Höfgen R and Willmitzer L (1988). Storage of competent cells for Agrobacterium transformation. Nucleic Acids Res. 16: 9877.

Hood E, Gelvin SB, Melchers L and Hoekema A (1993). New Agrobacterium helper plasmids for gene transfer to plants. Transgenic Res. 2: 208-218.

Jefferson RA, Kavanagh TA and Bevan MW (1987). GUS fusion: glucuronidase as a sensitive and versatile gene fusion marker in higher plants. EMBO J. 6: 3901-3907.

Jha P, Shashi, Rustagi A, Agnihotri PK, et al. (2011). Efficient Agrobacterium-mediated transformation of Pennisetum glaucum (L.) R. Br. using shoot apices as explant source. Plant Cell Tiss. Organ Cult. 107: 501-551.

Lacroix B and Citovsky V (2013). The roles of bacterial and host plant factors in Agrobacterium-mediated genetic transformation. Int. J. Dev. Biol. 57: 467-481.

Lange M, Vincze E, Moller MG and Holm PB (2006). Molecular analysis of transgene and vector backbone integration into the barley genome following Agrobacterium-mediated transformation. Plant Cell Rep. 25: 815-820.

Liu YG and Whittier RV (1995). Thermal asymmetric interlaced PCR: automatable amplification and sequencing of insert end fragments from P1 and YAC clones for chromosome walking. Genomics 25: 674-685.

Liu YG and Chen YL (2007). High-efficiency thermal asymmetric interlaced PCR for amplification of unknown flanking sequences. Biotechniques 43: 649-656.

Luxová M (1986). The seminal root primordia in barley and the participation of their non-meristematic cells in root construction. Biol. Plantarum 28: 161-167.

Murashige T and Skoog F (1962). A revised medium for rapid growth and bioassays with Tobacco tissue culture. Physiol. Plant 15:473-497.

Nagy B, Majer P, Mihály R, Dudits D, et al. (2011). Transient and transgenic approaches for functional testing of candidate genes in barley. Acta Biol. Szegediensis 55: 129-133.

Nelson AJ and Bushnell WR (1997). Transient expression of anthocyanin genes in barley epidermal cells: potential for use in evaluation of disease response genes. Transgenic Res. 6: 233-244.

Olhoft PM and Somers DA (2001). L-cysteine increases Agrobacterium-mediated T-DNA delivery into soybean cotyledonary-node cells. Plant Cell Rep. 20: 706-711.

Padilla IMG and Burgos L (2010). Aminoglycoside antibiotics: structure, functions and effects on in vitro plant culture and genetic transformation protocols. Plant Cell Rep. 29: 1203-1213.

Satoh N, Hong SK, Nishimura A, Matsuoka M, et al. (1999). Initiation of shoot apical meristem in rice: characterization 
of four SHOOTLESS genes. Development 126: 3629-3636.

Sticklen MB and Oraby H (2005). Shoot apical meristem: A sustainable explant for genetic engineering of cereal crops. In Vitro Cell. Dev. Biol. Plant 41: 187-200.

Tingay S, McElroy D, Kalla R, Fieg S, et al. (1997). Agrobacterium tumefaciens mediated barley transformation. Plant J. 11: 1369-1376.

Töpfer R, Gronenborn B, Schell J and Steinbiss HH (1989). Uptake and transient expression of chimeric genes in seedderived embryos. Plant Cell 1: 133-139.

Travella S, Ross SM, Harden J, Everett C, et al. (2005). A comparison of transgenic barley lines produced by particle bombardment and Agrobacterium-mediated techniques. Plant Cell Rep. 23: 780-789.

Ülker B, Li Y, Rosso MG, Logemann E, et al. (2008). T-DNA-mediated transfer of Agrobacterium tumefaciens chromosomal DNA into plants. Nat. Biotechnol. 26: 1015-1017.

Wan Y and Lemaux PG (1994). Generation of large numbers of independentlytransformed fertile barley plants. Plant Physiol. 104:37-48.

Wang Y, Gaba V, Wolf D, Xia XD, et al. (2000). Identification of a novel plant virus promoter using a potyvirus infectious clone. Virus Genes 20: 111-117.

Weining S and Langridge P (1991). Identificaiton and mapping of polymorphisms in cereals based on polymerase chain reaction. Theor. Appl. Genet. 82: 209-216.

Yang L, Fu FL, Zhang ZY, Zhou SF, et al. (2011). T-DNA integration patterns in transgenic plants mediated by Agrobacterium tumefaciens. Yi Chuan 59: 12614-12625.

Yang J, Yi J, Yang C and Li C (2013). Agrobacterium tumefaciens-mediated genetic transformation of Salix matsudana Koidz. using mature seeds. Tree Physiol. 33: 628-635

Yookongkaew N, Srivatanakul M and Narangajavana J (2007). Development of genotype-independent regeneration system for transformation of rice (Oryza sativa ssp. indica). J. Plant Res. 120 :237-245. 